\title{
Problems associated with a lipofuscin extraction method used to age blue crabs Callinectes sapidus cultured in Florida, USA
}

\author{
Claire E. Crowley ${ }^{1, *}$, Ryan L. Gandy ${ }^{1}$, Kendra L. Daly ${ }^{2}$, Edward S. Van Vleet ${ }^{2}$ \\ ${ }^{1}$ Florida Fish and Wildlife Conservation Commission, Fish and Wildlife Research Institute, 100 Eighth Ave SE, St. Petersburg, \\ Florida 33701, USA \\ ${ }^{2}$ University of South Florida, College of Marine Science, 140 Seventh Ave S, St. Petersburg, Florida 33701, USA
}

\begin{abstract}
The blue crab Callinectes sapidus is an ecologically and economically important component of marine and estuarine ecosystems of the western Atlantic and Gulf of Mexico. Current stock assessments lack a clear understanding of the age structure of blue crab populations in Florida (USA). Blue crabs and other crustaceans are especially difficult to age because of the complex nature of their discrete, rather than continuous, growth patterns. Chesapeake Bay researchers developed a method of aging blue crabs by assaying the aging pigment lipofuscin extracted from eyestalk nerve tissue. Here we investigated the usefulness of that method in determining the age of blue crabs inhabiting Florida waters. Assays of a wild-caught, young-of-theyear cohort that was pond-raised revealed a negative linear trend in lipofuscin indices over an 18 mo culture period. Assays of a tank-raised cohort of captive-bred crabs of known age also showed no relationship between the lipofuscin index and age over an 11 mo period. These results suggest that lipofuscin assays, as used in the Chesapeake Bay populations, are not useful in determining the age of blue crabs in Florida waters. Further study is warranted to determine how the procedure might be modified for Florida blue crab populations.
\end{abstract}

KEY WORDS: Callinectes sapidus $\cdot$ Blue crab $\cdot$ Aging $\cdot$ Lipofuscin

\section{INTRODUCTION}

Determination of age structure is essential to fishery stock assessments (Beamish \& McFarlane 1983). In the most recent stock assessment of Florida's blue crab Callinectes sapidus fishery (Murphy et al. 2007), it was noted that data on population age structure was particularly lacking. The means of determining age in blue crabs is a topic of scientific debate because of their complicated life cycle and inconsistent growth patterns. The main difficulty in aging crustaceans is that they periodically molt and do not retain mineralized structures (unlike finfish, whose age can be determined using structures such as otoliths, scales, and spines). The inability to accu-

${ }^{*}$ Corresponding author: claire.crowley@myfwc.com rately determine age makes proper modeling and management of the commercial blue crab fishery a challenge (Murphy et al. 2007, Puckett et al. 2008).

Length-frequency cohort analysis, although widely used in finfish fishery management, cannot be used to accurately determine the age of crustaceans (Puckett et al. 2008) because of growth rate variability, protracted spawning seasons, the inability to account for biological interactions, discrete growth, and the effects of environmental changes on ecdysis (Hartnoll 2001). The complex process of ecdysis, resulting in the growth of the blue crab, is greatly influenced by salinity and temperature (Steele \& Bert 1994). Temporal and spatial differences in temperature and salinity affect growth rates of individuals of

() The authors 2014. Open Access under Creative Commons by Attribution Licence. Use, distribution and reproduction are unrestricted. Authors and original publication must be credited. 
the same age in different ways resulting in body size being a poor indicator of age. Therefore age cannot be accurately determined by length and leaves length-based analysis highly uncertain (Murphy et al. 2007).

Lipofuscin is a fluorescent pigment that has been studied broadly through histology and microscopy since 1886 in vertebrate and invertebrate taxa for its role in senescence (Szweda et al. 2003, Cassidy 2008). Terman \& Brunk (2004a) stated that lipofuscin was an age pigment, regarding it as the 'hallmark of aging.' Lipofuscin is acquired in postmitotic cells (e.g. neurons and cardiac myocytes) as a function of oxidative stress and accumulates as a brown-yellow, autofluorescent, electron-dense material (Brunk \& Terman 2002). Through microscopy, lipofuscin in cells has been shown to increase linearly with age, making it a useful tool in age determination (Brunk \& Terman 2002, Terman \& Brunk 2004b). However, this histological method for assay of lipofuscin is expensive, labor intensive, time consuming, and results in small sample sizes.

Extraction of lipofuscin permits relatively rapid and inexpensive processing and analysis of a large number of samples, making it an appealing approach for determining the age composition of crustacean populations (Puckett et al. 2008). Ju et al. (1999, 2001) and Puckett et al. (2008) validated age estimates in blue crabs from Chesapeake Bay using this extraction method, finding a strong positive correlation between extracted lipofuscin levels and age of captivebred blue crabs reared under semi-wild pond conditions (Puckett et al. 2008). The correlation remained consistent even under varying environmental conditions (Harvey et al. 2008).

Comprehensive understanding of the age structure of Florida's blue crab populations would enhance the ability of fisheries managers to assess the blue crab fishery. The most recent Florida blue crab stock assessments utilized multiple methods of analysis, but these methods failed to reach a consensus on the status of the fishery (Murphy et al. 2007), in large part due to the lack of information on population age structure. Because it proved useful in Chesapeake Bay populations, lipofuscin extraction and analysis seemed to promise an inexpensive way to rapidly determine the age structure of Florida populations through robust sample sizes. In 2008, we sought to first validate and then apply the lipofuscin extraction methodology of Ju et al. (1999, 2001), Puckett et al. (2008), and Harvey et al. (2008), to characterize the age structure of the blue crab population in Florida.

\section{MATERIALS AND METHODS}

Two cohorts of juvenile blue crabs were obtained to validate the efficacy of the extraction method. The first cohort was a wild-caught young-of-theyear cohort from Tampa Bay, Florida. The second was a cohort of known-age juvenile crabs provided by the Blue Crab Aquaculture Program at the University of Southern Mississippi's Gulf Coast Research Laboratory (USM/GCRL) and transported to Florida for use in this study. The 2 populations were cultured under different conditions (open pond vs. covered tanks) to determine whether the lipofuscin aging method was robust and reliable before its application to Florida blue crab populations. Provided the method proved robust and reliable, further studies would develop a known-age calibration curve for assaying the age of crab populations in the Florida blue crab fishery.

The wild-caught cohort from Tampa Bay was collected in September 2010 using a $6.1 \mathrm{~m}$ otter trawl near the mouth of the Little Manatee River $\left(27^{\circ} 44^{\prime} 44.22^{\prime \prime} \mathrm{N}, 82^{\circ} 29^{\prime} 46.69^{\prime \prime} \mathrm{W}\right)$. The net bar of the trawl was $8.2 \mathrm{~m}$ wide, and the cod end of the net was composed of $38 \mathrm{~mm}$ stretch mesh, with a $3 \mathrm{~mm}$ mesh liner. Approximately $620 \mathrm{crabs}$, ranging from 8 to $20 \mathrm{~mm}$ carapace width, were removed from the trawl and transported to the Stock Enhancement Research Facility (SERF) in Ruskin, Florida. Crabs were first placed in a $10 \mathrm{~m}$ diameter acclimation tank system with water of the same salinity and temperature as the study pond. After $7 \mathrm{~d}$, the 570 crabs that survived were then transferred to the quarter-acre (ca. $1012 \mathrm{~m}^{2}$ ) study pond for the remainder of the experiment.

Natural forage available to the crabs included grass shrimp Palaemonetes spp., sailfin mollies Poecilia latipinna, and killifish Fundulus spp. In order to reduce cannibalism, fresh feed consisting of frozen cigar minnows Decapterus punctatus and squid Loligo opalescens was provided daily at amounts equivalent to 2 to $4 \%$ of the estimated total biomass of crabs in the pond. Six feed trays were used to monitor feed consumption. Approximately $10 \%$ of the daily ration was divided between the feed trays and checked before the next day's feeding. When feed trays still contained feed after $24 \mathrm{~h}$, the next feeding was reduced or skipped. At no point was food availability limited.

The pond was monitored hourly for temperature with a HOBO Pendant Temperature/Light Data Logger (Onset). Pond water quality was monitored daily for temperature, salinity, $\mathrm{pH}$, and dissolved 
oxygen using a Hydrolab MS5 Sonde (HACH Environmental). The pond was partially flushed bimonthly with seawater and freshwater to maintain $\mathrm{pH}$ between 8 and 9.5, and salinity levels similar to the source water of Tampa Bay (27-34 PSU). In May 2011, we reduced salinity to 11 PSU, where it was maintained through the end of the study; the purpose was to reduce the prevalence and impact of Hematodinium sp., a parasitic dinoflagellate present in the pond. The salinity thereafter was maintained in a manner consistent with previous lipofuscin studies of Ju et al. (1999, 2001, 2003), viz. 10 to 15 PSU.

Quarterly, 24 crabs were trapped with baited commercial blue crab traps. Crabs were weighed and sexed, carapace width was measured, and maturity in females was recorded based on abdomen shape. Crabs were then taken live to the laboratory, where eyestalks were dissected and analyzed for lipofuscin concentration. In addition to this quarterly sampling for lipofuscin, 20 to 70 individuals were trapped weekly for measurement of carapace width and length, weighing, and sexing, and returned to the pond.

Approximate age at capture for this wild-caught cohort was determined by calculating the timing of larval metamorphosis and postlarval growth rates of crabs using the temperature and salinity readings at the time of capture and the findings of Costlow \& Bookhout (1959) and Millikin \& Williams (1984). The temperature and salinity at the time of collection were $28^{\circ} \mathrm{C}$ and $28 \mathrm{PSU}$. Based on previous findings at $25^{\circ} \mathrm{C}$ and $27 \mathrm{PSU}$, the metamorphosis for zoeal and megalopae stages proceeded over an average period of 37 to $45 \mathrm{~d}$ (Costlow \& Bookhout 1959, Millikin \& Williams 1984). In addition, it has been shown that juvenile crabs molt approximately every $11 \mathrm{~d}$ under similar conditions, increasing in carapace width each time by 25 to $50 \%$ (Tagatz 1968, Cadman \& Weinstein 1988). The average carapace width of the crabs collected was $15.6 \pm 5.8 \mathrm{~mm}$. These growth rate parameters and the size of crabs when collected suggest that the wild cohort of crabs were between 11 and 20 wk old.

The known-age group was transported to the SERF for an additional lipofuscin trial from November 2011 to October 2012. This population of crabs was used to investigate the repeatability of the lipofuscin extraction method used on the pond-raised cohort. It comprised 188 crabs that were 9 wk old with an average carapace width of $13.9 \pm 2.6 \mathrm{~mm}$. There were too few crabs to stock into a quarteracre pond with hopes of recapturing them for analy- sis. Crabs were therefore held in a greenhouseenclosed structure that contained 16 tanks (each $4 \mathrm{~m}^{3}$ ). Each crab was confined in a cylindrical, $0.04 \mathrm{~m}^{3}$ cage to prevent cannibalism, and 12 crabs were housed in each tank. Tanks were filled with a combination of well water and Tampa Bay water to attain a salinity of 11 PSU. Crabs were fed 3 times a week; diet included pellet feed, frozen squid $L$. opalescens, and cigar minnows D. punctatus. Each was provided to the population on an alternating schedule to ensure adequate nutrition. Each tank was monitored hourly for temperature with a HOBO Pendant Temperature/Light Data Logger. Salinity and dissolved oxygen were monitored daily with a Hydrolab MS5 Sonde.

Each month, 13 crabs were randomly selected for lipofuscin analysis. Crabs were weighed and sexed and their carapace width measured; maturity in females was recorded based on abdomen shape; and the general state of health was recorded. Crabs were then taken live to the laboratory, where eyestalks were dissected and analyzed for lipofuscin concentration. In addition to this monthly sampling for lipofuscin, $10 \%$ of the population was sampled weekly for measurement of carapace width and length, weighing, and sexing, and returned to the tanks.

\section{Extraction protocol}

Lipofuscin was extracted and assayed following $\mathrm{Ju}$ et al. (1999) and Dickinson et al. (2006). Carapace width (spine to spine carapace), carapace length (anterior to posterior carapace), and weight were measured; molt stage (Freeman et al. 1987) and sex were determined; and visible injuries were noted. Crabs were anesthetized in an ice bath. Eyestalks were removed and tissue from the external portion of the eyestalks was excised from the structural chitin. No retinal tissue from the eye was included, which could have caused overlapping in fluorescence readings with that of lipofuscin (retinal material: excitation range $325-340 \mathrm{~nm}$, emission $475 \mathrm{~nm}$; lipofuscin: excitation $340 \mathrm{~nm}$, emission $405 \mathrm{~nm}$; Hill \& Womersley 1991). External eyestalk tissue was then placed in a $4 \mathrm{ml}$ amber vial containing $2 \mathrm{ml}$ of $2: 1$ dichloromethane-methanol $\left(\mathrm{CH}_{2} \mathrm{Cl}_{2}-\mathrm{MeOH}\right)$. Vials were placed on ice and sonicated at $20 \mathrm{~W}$ for $2 \mathrm{~min}$ to extract the lipofuscin; the vials were then centrifuged at $1380 \times g$ for 10 min using a Fisher Scientific Centrific Model 228 benchtop centrifuge. The supernatant was transferred by pipette to a clean $4 \mathrm{ml}$ amber vial. The supernatant was dried under pres- 
surized $\mathrm{N}_{2}$ and the pellet redissolved in $4 \mathrm{ml}$ of methanol $(\mathrm{MeOH})$. A $1 \mathrm{ml}$ aliquot was removed and set aside for protein analysis. The fluorescence of the remaining $3 \mathrm{ml}$ was measured (maximum excitation $340 \mathrm{~nm}$, maximum emission $405 \mathrm{~nm}$ ) using a Jasco FP 6200 Routine Fluorescence Spectrophotometer. Fluorescence readings were calibrated against a quinine sulfate calibration curve (quinine sulfate dissolved in $0.1 \mathrm{~N}$ sulfuric acid) to achieve concentrations of 0 to $0.25 \mu \mathrm{g} \mathrm{mg}^{-1}$ quinine sulfate after Ju et al. (1999) to achieve a quantitative measure of lipofuscin. Protein was analyzed using a Fisher bicinchoninic acid (BCA) protein assay kit (PI-23225) to normalize fluorescence readings to protein concentrations. The lipofuscin index was calculated as follows: lipofuscin index ( $\mu \mathrm{g}$ lipofuscin $\mathrm{mg}^{-1}$ protein) = lipofuscin concentration $\left(\mu \mathrm{g} \mathrm{ml}^{-1}\right) /$ total protein content $\left(\mathrm{mg} \mathrm{ml}^{-1}\right)$.

\section{Statistical analysis}

Statistical analyses were performed using SPSS version 19.0. Lipofuscin indices were natural logtransformed to satisfy assumptions of normality and homogeneity of variance. Regression analysis was performed between lipofuscin indices and age for pond and greenhouse populations. Pearson correlations were used for temperature analysis between pond and Tampa Bay data. All statistical analyses were performed at $\alpha=0.05$.

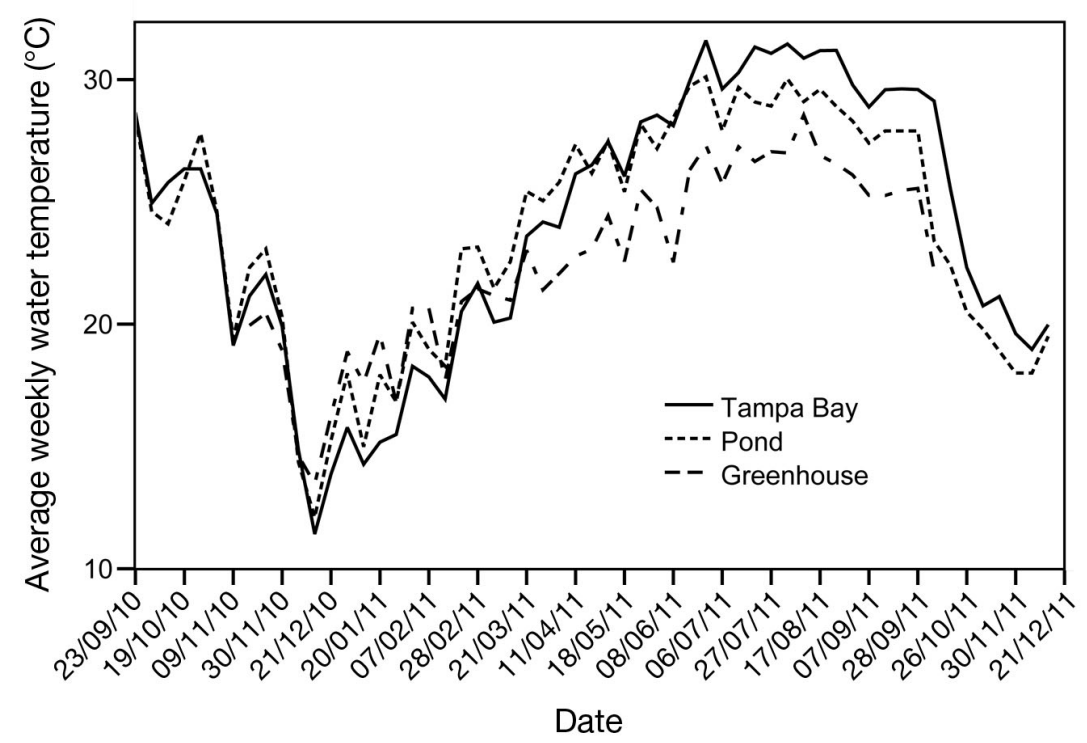

Fig. 1. Mean water temperatures from Tampa Bay, Florida (USA) (University of South Florida 2014), the Stock Enhancement Research Facility (SERF) blue crab Callinectes sapidus pond, and the SERF greenhouse tanks. Pearson correlation between pond and Tampa Bay: $\mathrm{n}=44, \mathrm{r}=0.980, \mathrm{p}<0.001$, Pearson correlation between greenhouse tanks and Tampa Bay: $\mathrm{n}=43, \mathrm{r}=0.952, \mathrm{p}<0.001$

\section{RESULTS}

\section{Water quality in pond and tanks}

Mean pond temperature ranged from 12.1 to $30.1^{\circ} \mathrm{C}$ (Fig. 1). Mean weekly water temperatures for Tampa Bay were similar to the temperature regime of the pond (Pearson correlation: $\mathrm{n}=57, \mathrm{r}=0.961, \mathrm{p}<0.001$ ). Salinity in the pond ranged from 9.8 to 28.5 PSU. After May 2011, a salinity of 11 PSU was maintained for the duration of the study by the addition of freshwater. Pond-water $\mathrm{pH}$ ranged from 8.0 to 9.5, and dissolved oxygen ranged from 4.0 to $10.7 \mathrm{mg} \mathrm{l}^{-1}$.

Mean tank temperatures ranged from 13.5 to $28.6^{\circ} \mathrm{C}$ (Fig. 1). Mean weekly water temperatures for the tank system were significantly correlated with the temperature regime of the pond (Pearson correlation: $\mathrm{n}=43, \mathrm{r}=0.958, \mathrm{p}<0.001$ ) and Tampa Bay (Pearson correlation: $\mathrm{n}=43, \mathrm{r}=0.952, \mathrm{p}<0.001$ ). Salinity in the tanks was maintained at approximately 11 PSU. Tank-water $\mathrm{pH}$ remained steady at 8.3, and dissolved oxygen ranged from 4.8 to $11.4 \mathrm{mg} \mathrm{l}^{-1}$.

\section{Growth}

Weekly measurements of trapped individuals from the pond-reared cohort revealed rapid growth in carapace width between September 2010 and January 2011. Growth slowed beginning in January 2011, but continued to increase until the final sample (Fig. 2). Weekly measurements of tank-reared population subsamples revealed a gradual increase in carapace width between November 2010 and April 2011. Individuals remaining after April 2011 grew more rapidly throughout the remainder of the study (Fig. 3).

\section{Lipofuscin analysis in pond- and tank-reared crabs}

Eyestalks from a total of 137 pondreared crabs were analyzed for lipofuscin concentration, and the mean lipofuscin concentration was determined for each sample date to avoid bias of pseudoreplication in sampling from a single pond (Hurlbert 1984). Although lipofuscin values varied widely among individual crabs, regression analyses revealed a negative linear relationship 


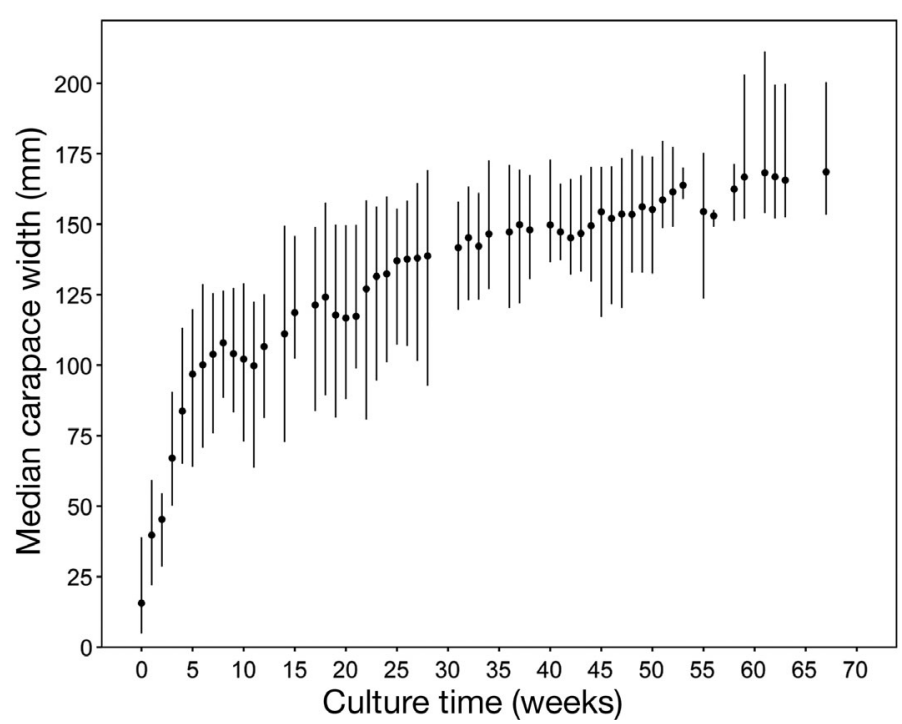

Fig. 2. Median carapace width of pond-reared blue crabs Callinectes sapidus, collected weekly over the study period. Bars represent carapace width range $(\mathrm{mm})$ in weekly sample

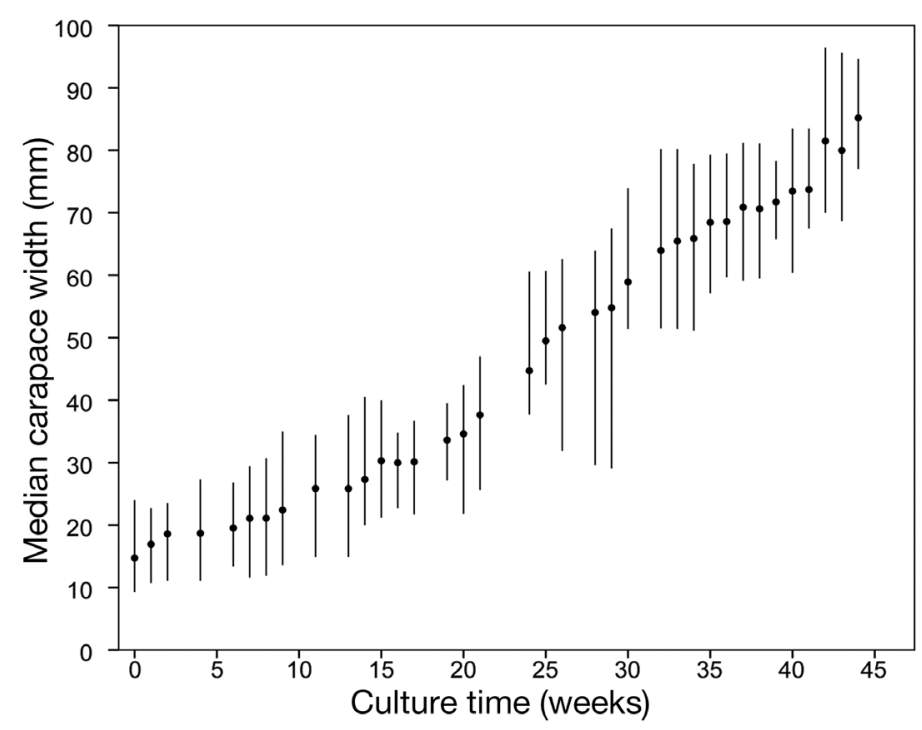

Fig. 3. Median carapace width of tank-reared blue crabs Callinectes sapidus, collected weekly over the study period. Bars represent carapace width range ( $\mathrm{mm}$ ) in weekly sample

between the mean lipofuscin index and time among these crabs ( $\mathrm{n}=7 ; \mathrm{p}<0.05$; Fig. 4).

Lipofuscin indices were determined for 80 tankreared individuals over the sample period. Regression analysis revealed no significant relationship between mean lipofuscin concentration and time $(\mathrm{n}=7 ; \mathrm{p}<0.05 ;$ Fig. 5). The lipofuscin analysis of this population performed similarly to the pond-reared crabs, i.e. lipofuscin indices of the oldest crab were the same as or lower than those of younger crabs.

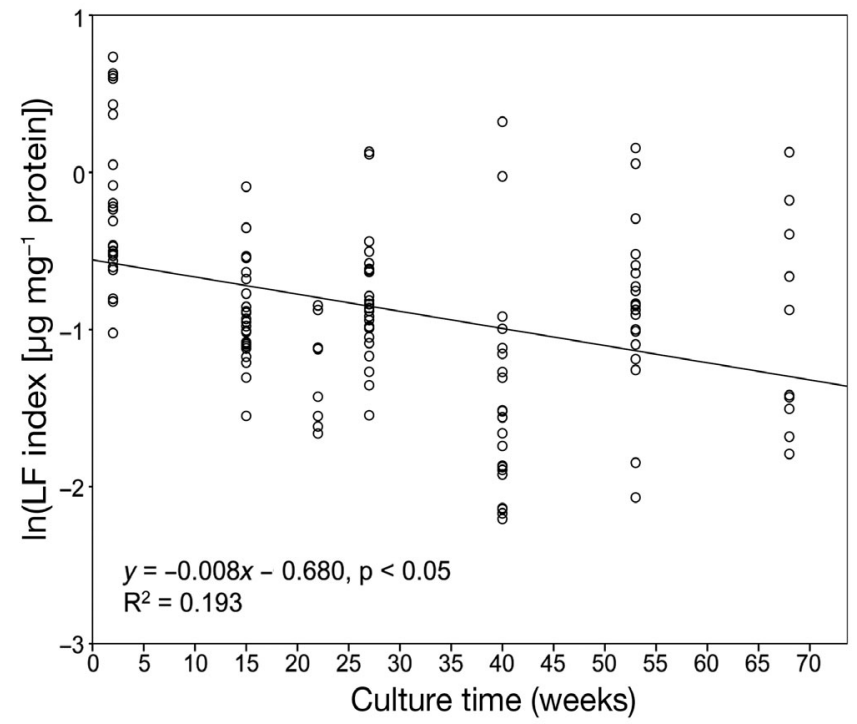

Fig. 4. Linear regression relationship between culture time and mean lipofuscin (LF) index of pond-reared blue crabs Callinectes sapidus

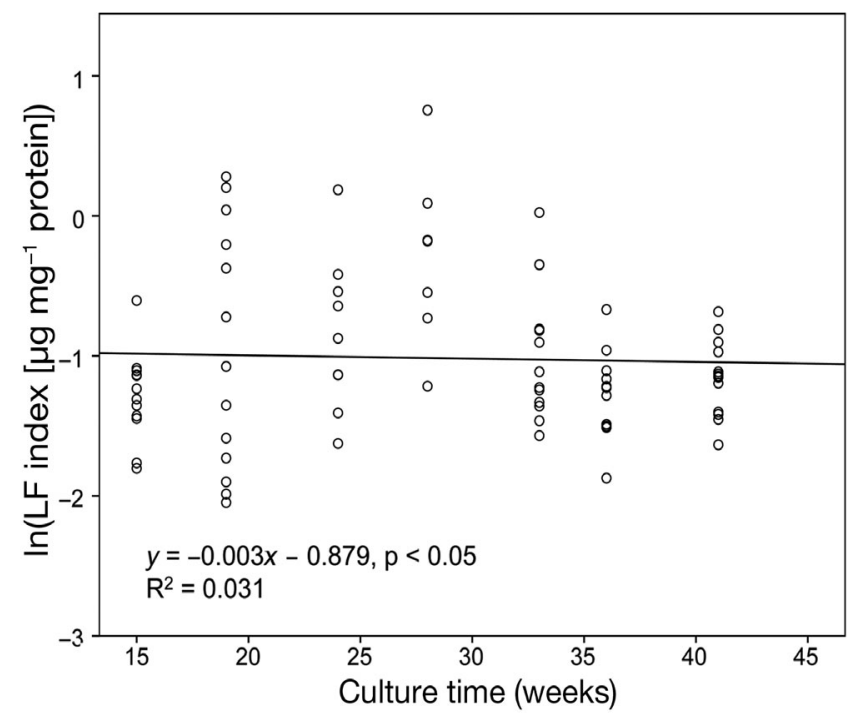

Fig. 5. Regression relationship between culture time and mean lipofuscin (LF) index of tank-reared blue crabs Callinectes sapidus

\section{DISCUSSION}

Lipofuscin indices were determined for 2 populations of blue crabs in order to investigate whether the methodology of aging crabs using lipofuscin extraction and normalization to protein could be applied to blue crabs inhabiting Florida waters. The extraction technique has been applied to a number of marine species, including ghost shrimp Neotrypaea californiensis (Bosley \& Dumbauld 2011), euphausiids 
Euphausia pacifica and E. superba (Harvey et al. 2010), blue crab Callinectes sapidus (Ju et al. 1999, 2001, Dickinson et al. 2006, Puckett et al. 2008), a teleost, Oreochromis mossambicus (Hill \& Womersley 1991), western rock lobster Panulirus cygnus, scampi Metanephrops andamanicus (Crossland et al. 1988), spider crab Hyas araneus (Hirche \& Anger 1987), and the terrestrial fleshfly Sarcophaga bullata (Ettershank et al. 1983), all of which showed an accumulation of lipofuscin with increasing age in both extraction and histological analyses. In contrast, we found that blue crabs living in tanks for $11 \mathrm{mo}$ or in a pond for 18 mo did not show a linear increase in lipofuscin over time. A decline in lipofuscin with time was observed for blue crabs cultured in the pond, and no relationship between lipofuscin concentration and time was detected for the blue crabs cultured in tanks.

The exact hatch date of the wild-caught cohort could not be explicitly calculated because of variation in size of individuals. Growth studies by Costlow \& Bookhout (1959) demonstrate the variability in size of blue crabs of similar age. Growth in blue crabs is dependent on food availability, temperature, and salinity. Regardless of the average age of this youngof-the-year cohort, at the time of collection, they represented a wild cohort of similar age and what might be encountered when applying this method to a fished population. Once in the pond, this closed population was sampled over the course of the study, and the lipofuscin indices of the population would be expected to show accumulation of the compound over time and not the observed decrease. A negative, although less steep, linear trend was also observed in the tank-raised, known-age population, suggesting that observations from the pond-raised, wild-caught cohort are valid regardless of our ability to determine the exact age of the population at the start of the study.

Using a similar method (fluorescent excitation at $345 \mathrm{~nm}$ and emission at $445 \mathrm{~nm})$, Manibabu \& Patnaik (1997) and Majhi et al. (2000) noted the lack of a positive trend between lipofuscin and time in the brains of male garden lizards. In addition, Sheehy (2008) raised concerns that this extraction method had not been sufficiently vetted for use in age determination. The lack of validation of the lipofuscin method in our blue crab study and in studies of other species indicates that the method should be used only after a rigorous validation. A number of factors may have contributed to the observed decrease in lipofuscin levels in blue crabs in this study, including (1) the inability to accurately extract lipofuscin from neural tissues; (2) the possible unsuitability of protein for standardization of lipofuscin concentrations; and (3) possible false positives resulting from the detection of other compounds that extract and fluoresce in a manner similar to lipofuscin.

Lipofuscin autofluoresces and has been thoroughly documented in many organisms through in situ experimentation. However, due to the heterogeneity of the compound, when identified and quantified through microscopy versus spectrofluorometric measurements of extracted lipofuscin, a problem arises (Yin \& Brunk 1991). Microscopists have observed lipofuscin granules emitting yellow-orange or brown-red autofluorescence in intracellular lysosomal bodies of postmitotic tissues (Yin \& Brunk 1991, Katz \& Robison 2002), when excited with UV and blue wavelengths of 450 to $640 \mathrm{~nm}$ (Sheehy 1990, Yin \& Brunk 1991, Medina et al. 2000, Katz \& Robison 2002, Li et al. 2006, Pereira et al. 2010). These emission wavelengths are not consistent with those reported for the blue crab by Ju et al. $(1999,2001)$ and Puckett et al. (2008), who read emission maxima at the violet peak of $405 \mathrm{~nm}$. Yin \& Brunk (1991) suggested that the extraction technique results in a more dilute sample than does histology, causing a 'quenching' or spectral shift in emissions down to the blue range of 400 to $490 \mathrm{~nm}$ (Yin \& Brunk 1991).

The lipofuscin extraction methodology specifically operates under the assumption that lipid peroxidation is a precursor to lipofuscin accumulation (Chio et al. 1969, Sheehy 2008). While lipofuscin does derive from native lipid peroxidation, more recent molecular analysis has shown that it may not, in fact, be the source of extractable autofluorescence (Schutt et al. 2003, Szweda et al. 2003, Sheehy 2008). Palmer et al. (2002) hypothesized that the fluorescence was in fact a type of light scatter due to the packing of protein molecules into subcellular organelles (Sheehy 2008). Additionally, this fluorescence also relates to the presence of malondialdehyde, an additional product of lipid peroxidation, but not in fact lipofuscin (Yin \& Brunk 1991). Understanding the origin and properties of the molecules that autofluoresce is crucial in identifying the compound of interest (Sheehy 2008).

Another issue that may arise with the lipofuscin extraction method is the normalization of lipofuscin to the mass of tissue. The tissue mass used for each lipofuscin assay is dependent on the size of the animal sacrificed. In an effort to account for this variability, the extraction methodology normalizes lipofuscin to protein. Due to the small cellular nature of the lipofuscin compounds, significant dilution occurs in the extraction process (Yin \& Brunk 1991). If the protein 
concentration varies significantly more than does lipofuscin concentration, it may skew the lipofuscinto-protein ratio, rendering the lipofuscin index an unreliable indicator of crab age.

Interference from compounds other than lipofuscin may have created false detection in the current study. Autofluorescent compounds not associated with lipofuscin may have been present in blue crab tissues. Because those compounds cannot be differentiated or quantified, we are unable to specifically quantify lipofuscin (Udenfriend 1962, 1969, Sheehy \& Ettershank 1988, Brunk \& Terman 2002). When Crossland et al. (1988) examined different tissues for fluorescence emission maxima, they found differences in lipofuscin concentrations between tail muscle, antenna muscle, cerebral ganglia, heart tissue, pereopods, and eyestalks. This is possibly due to the interaction of different fluorophores and absorbing molecules in the extracts (Crossland et al. 1988). Compounds that exhibit fluorescence properties similar to those of lipofuscin include simple proteins, carotenoids, folic acid derivatives, and pyridine nucleotides (Sheehy et al. 1996, Sheehy 2008). In arthropods, pteridine compounds accumulate over time and are also identified by similar fluorescence wavelengths (Sheehy 2008). Robson \& Crozier (2009) compared the accumulation of pteridines and lipofuscin in the social ant Polyrhachis sexpinosa. Pteridine and lipofuscin extracts were excited at 355 and $340 \mathrm{~nm}$ and produced emissions at 445 and $410 \mathrm{~nm}$, respectively. Over a period of $200 \mathrm{~d}$, that study confirmed quantifiable levels of both substances. Most notably, pteridine concentration increased with weight but was independent of age (Robson \& Crozier 2009). Although little research has been done on the occurrence and distribution of pteridines in crustaceans, Waywell \& Corey (1972) examined pteridines in 9 species of crayfish and determined that the hypodermis and eyestalks had the greatest concentration of pteridines. While the function of pteridines is not completely understood, there is agreement that this compound is present in eyestalks of crustaceans (Waywell \& Corey 1972).

The similarity of techniques for identifying multiple compounds, which may or may not accumulate with age, poses a large problem for quantifying lipofuscin through extraction. In addition, the lack of ability to purify the lipofuscin compound may increase the probability of interference by nontargeted compounds. If the application of lipofuscin extraction is to be of value to managers in the Florida blue crab fishery, the method must undergo further validation to ensure that accurate age determinations can be made.
Acknowledgements. This research was funded through the NOAA Interjurisdictional Marine Fisheries Research Program grant \#NA05NMF4070034. We thank our colleagues at the Florida Fish and Wildlife Conservation CommissionFish and Wildlife Research Institute and the Stock Enhancement Research Facility for their input, time, and expertise on blue crabs and aquaculture that made this research possible.

\section{LITERATURE CITED}

Beamish RJ, McFarlane GA (1983) The forgotten requirement for age validation in fisheries biology. Trans Am Fish Soc 112:735-743

> Bosley KM, Dumbauld BR (2011) Use of extractable lipofuscin to estimate age structure of ghost shrimp populations in west coast estuaries of the USA. Mar Ecol Prog Ser 428:161-176

Brunk UT, Terman A (2002) Lipofuscin: mechanisms of agerelated accumulation and influence on cell function. Free Radic Biol Med 33:611-619

> Cadman LR, Weinstein MP (1988) Effects of temperature and salinity on the growth of laboratory-reared juvenile blue crabs Callinectes sapidus Rathbun. J Exp Mar Biol Ecol 121:193-207

Cassidy KM (2008) Use of extractable lipofuscin as an age biomarker to determine age structure of ghost shrimp (Neotrypaea californiensis) populations in West Coast estuaries. MSc thesis, Oregon State University, Corvallis, OR

Chio KS, Reiss U, Fletcher B, Tappel AL (1969) Peroxidation of subcellular organelles: formation of lipofuscinlike fluorescent pigments. Science 166:1535-1536

Costlow JD Jr, Bookhout CG (1959) The larval development of Callinectes sapidus Rathbun reared in the laboratory. Biol Bull (Woods Hole) 116:373-396

Crossland CJ, Denby G, Phillips BF, Brown R (1988) The use of fluorescent pigments (lipofuscin) for ageing western rock lobster (Panulirus cygnus) and scampi (Metanephrops andamanicus): a preliminary assessment. CSIRO Marine Laboratories Report No 195. CSIRO, Hobart

Dickinson GH, Rittschof D, Latanich C (2006) Spawning biology of the blue crab, Callinectes sapidus, in North Carolina. Bull Mar Sci 79:273-285

- Ettershank G, Macdonnell I, Croft R (1983) The accumulation of age pigment by the fleshfly Sarcophaga bullata Parker (Diptera: Sarcophagidae). Aust J Zool 31:131-138

> Freeman JA, Kilgus G, Laurendeau D, Perry HM (1987) Postmolt and intermolt molt cycle stages of Callinectes sapidus. Aquaculture 61:201-209

> Hartnoll RG (2001) Growth in Crustacea: twenty years on. Hydrobiologia 449:111-122

> Harvey HR, Secor DH, Ju SJ (2008) The use of extractable lipofuscin for age determination of crustaceans: reply to Sheehy (2008). Mar Ecol Prog Ser 353:307-311

> Harvey HR, Ju SJ, Son SK, Feinberg LR, Shaw CT, Peterson WT (2010) The biochemical estimation of age in euphausiids: laboratory calibration and field comparisons. DeepSea Res II 57:663-671

Hill KT, Womersley C (1991) Critical aspects of fluorescent age-pigment methodologies: modification for accurate analysis and age assessments in aquatic organisms. Mar Biol 109:1-11

Hirche HJ, Anger K (1987) The accumulation of age pigments during larval development of the spider crab, 
Hyas araneus (Decapoda, Majidae). Comp Biochem Physiol B Biochem Mol Biol 88:777-782

Hurlbert SH (1984) Pseudoreplicaiton and the design of ecological field experiments. Ecol Monogr 54:187-211

> Ju SJ, Secor DH, Harvey HR (1999) Use of extractable lipofuscin for age determination of blue crab Callinectes sapidus. Mar Ecol Prog Ser 185:171-179

> Ju SJ, Secor DH, Harvey HR (2001) Growth rate variability and lipofuscin accumulation rates in the blue crab Callinectes sapidus. Mar Ecol Prog Ser 224:197-205

Ju SJ, Secor DH, Harvey HR (2003) Demographic assessment of the blue crab (Callinectes sapidus) in Chesapeake Bay using extractable lipofuscins as age markers. Fish Bull 101:312-320

Katz ML, Robison WG Jr (2002) What is lipofuscin? Defining characteristics and differentiation from other autofluorescent lysosomal storage bodies. Arch Gerontol Geriatr 34:169-184

Li G, Liao Y, Wang X, Sheng S, Yin D (2006) In situ estimation of the entire color and spectra of age pigment-like materials: application of a front-surface 3D-fluorescence technique. Exp Gerontol 41:328-336

Majhi S, Jena BS, Patnaik BK (2000) Effect of age on lipid peroxides, lipofuscin and ascorbic acid contents of the lungs of male garden lizard. Comp Biochem Physiol C Toxicol Pharmacol 126:292-298

Manibabu PV, Patnaik BK (1997) Lipofuscin concentration of the brain shows a reduction with age in male garden lizard. Comp Biochem Physiol C Pharmacol Toxicol Endocrinol 117:229-232

Medina A, Vila Y, Megina C, Sobrino I, Ramos F (2000) A histological study of the age-pigment, lipofuscin, in dendrobranchiate shrimp brains. J Crustac Biol 20:423-430

Millikin MR, Williams AB (1984) Synopsis of biological data on the blue crab, Callinectes sapidus Rathbun. NOAA Tech Rep NMFS 1. FAO Fisheries Synopsis No. 138. US Dept Commerce, NOAA, NMFS, Washington, DC

Murphy MD, McMillen-Jackson AL, Mahmoudi B (2007) A stock assessment for the blue crab, Callinectes sapidus, in Florida waters. Report to the Florida Fish and Wildlife Commission Division of Marine Fisheries Management, IHR 2007-006. Florida Fish and Wildlife Conservation Commission-Fish and Wildlife Research Institute, St. Petersburg, FL

Palmer DN, Oswald MJ, Westlake VJ, Kay GW (2002) The origin of fluorescence in the neuronal ceroid lipofuscinoses (Batten disease) and neuron cultures from affected sheep for studies of neurodegeneration. Arch Gerontol Geriatr 34:343-357

> Pereira CR, D'Incao F, Fonseca DB (2010) Bilateral comparison of in situ neurolipofuscin accumulation in Callinectes sapidus caught in the wild. J Mar Biol Assoc UK 90: 563-567

Puckett BJ, Secor DH, Ju SJ (2008) Validation and application of lipofuscin-based age determination for Chesa-

Editorial responsibility: Christine Paetzold,

Oldendorf/Luhe, Germany peake Bay blue crabs Callinectes sapidus. Trans Am Fish Soc 137:1637-1649

Robson SKA, Crozier RH (2009) An evaluation of two biochemical methods of age determination in insects (pteridines and lipofuscins) using the ant Polyrhachis sexpinosa Latrielle (Hymenoptera: Formicidae). Aust J Entomol 48:102-106

Schutt F, Bergmann M, Holz FG, Kopitz J (2003) Proteins modified by malondialdehyde, 4-hydroxynonenal, or advanced glycation end products in lipofuscin of human retinal pigment epithelium. Invest Opthalmol Vis Sci 44: 3663-3668

Sheehy MRJ (1990) Widespread occurrence of fluorescent morphological lipofuscin in the crustacean brain. J Crustac Biol 10:613-622

Sheehy MRJ (2008) Questioning the use of biochemical extraction to measure lipofuscin for age determination of crabs: comment on Ju et al. $(1999,2001)$. Mar Ecol Prog Ser 353:303-306

Sheehy MRJ, Ettershank G (1988) Extractable age pigmentlike autofluorescence and its relationship to growth and age in the water-flea Daphnia carinata King (Crustacea: Cladocera). Aust J Zool 36:611-625

Sheehy MRJ, Shelton PMJ, Wickins JF, Belchier M, Gaten E (1996) Ageing the European lobster Homarus gammarus by the lipofuscin in its eyestalk ganglia. Mar Ecol Prog Ser 143:99-111

Steele P, Bert TM (1994) Population ecology of the blue crab, Callinectes sapidus Rathbun, in a subtropical estuary: population structure, aspects of reproduction, and habitat partitioning. Fla Mar Res Publ 51:1-24

Szweda PA, Camouse M, Lundberg KC, Oberley TD, Szweda LI (2003) Aging, lipofuscin formation, and free radicalmediated inhibition of cellular proteolytic systems. Ageing Res Rev 2:383-405

Tagatz ME (1968) Growth of juvenile blue crabs, Callinectes sapidus Rathbun, in the St. Johns River, Florida. Fish Bull 67:281-288

Terman A, Brunk UT (2004a) Aging as a catabolic malfunction. Int J Biochem Cell Biol 36:2365-2375

Terman A, Brunk UT (2004b) Lipofuscin. Int J Biochem Cell Biol 36:1400-1404

Udenfriend S (1962) Fluorescence assay in biology and medicine, Vol 1. Academic Press, New York, NY

Udenfriend S (1969) Fluorescence assay in biology and medicine, Vol 2. Academic Press, New York, NY

University of South Florida (2014) Manatee county water atlas. www.manatee.wateratlas.usf.edu/datadownload/Select Stations.aspx (accessed 7 Jan 2014)

> Waywell EB, Corey S (1972) The occurence and distribution of pteridines and purines in crayfish (Decapoda, Astacidae). Crustaceana 22:294-302

> Yin D, Brunk UT (1991) Microfluorometric and fluorometric lipofuscin spectral discrepancies: a concentration-dependent metachromatic effect? Mech Ageing Dev 59:95-109

Submitted: January 29, 2014; Accepted: April 30, 2014

Proofs received from author(s): June 18, 2014 